\title{
Human Aspects of Agile Transition in Traditional Organizations
}

\author{
Mariângela Pinton ${ }^{1 *}$, Alvair Silveira Torres Junior ${ }^{1}$
}

\begin{abstract}
The agile transition is crucial for traditional organizations to remain competitive in the current market, which is characterized by a fastpace and a constant need for innovation. In order to implement this transition, organizations must adjust their mindset to the new agile values. Despite its evident benefits, the transition to agile model is complex and time-consuming, posing many challenges to organizations. Since the agile philosophy is people-centered, rather than process-centered, most challenges are related to the human aspects of this transition and they demand a large transformation in all areas of the organization. This article provides a Systematic Literature Review (SLR) of the human aspects of agile transition and summarizes the existing literature into three categories: People, Management and Organization. Its main objective is to assist organizations undergoing agile transition in reducing risks related to this process, by acquiring knowledge on the challenges involved and implementing the proposed recommendations.
\end{abstract}

Keywords: Project Management Models; Agile Transition; Agile Software Development; Agile Adoption Challenges; Agile Transformation Process; Human-related challenges.

Submitted: May $20^{\text {th }}, 2020 /$ Approved: October $28^{\text {th }}, 2020$

\section{Introduction}

The current market scenario amid the Digital Transformation is characterized by profound changes in technology, connecting virtual and physical worlds through products and services digitalization (Means \& Schwab, 2015). Even non-technology organizations running traditional business - where technology is used only for value generation must transform themselves to meet the new customers' demands and offer them innovative products and services.

Thus, it is imperative for organizations to focus on the implementation of digital products and services to meet their customers' expectations. In addition, they should develop and adopt appropriate Project Management Models (PMMs) for software development, aiming to launch their products and services efficiently and at the lowest possible risk. That is why PMMs are always evolving and being adjusted to fit the changing market demands, so that organizations can deliver products and services at the lowest cost and in the shortest time-tomarket (Chen, Ravichandar, \& Proctor, 2016).

In that regard, new software development PMMs have emerged since 2001 to make these processes more simple and flexible, based on functionalities prioritization turned to their business value (Schwaber \& Sutherland, 2017). These models, also known as Agile, aim to support organizations on delivering digital products and services focused on customers' needs (Lee et al., 2018).

The Agile PMMs allow organizations to respond to this new accelerated and uncertain scenario by means of short development cycles and rapid response to the frequent changes called for the market. Many start-ups founded after 2001 have always used Agile PMMs to manage their software development projects. Nevertheless, older organizations, which were used to traditional PMMs, had to change their internal processes in order to implement the new model.
Despite the benefits of the agile model, there are several challenges associated to this transition, making it complex and time consuming (Gandomani, Zulzalil, Ghani, Sultan, \& Nafchi, 2013; Javdani Gandomani \& Ziaei Nafchi, 2015; Taghi Javdani Gandomani, Hazura Zulzalil, Abdul Azim Abdul Ghani, Abu Bakar Md. Sultan, \& Khaironi Yatim Sharif, 2014). Nevertheless, the agile transition is paramount for traditional organizations, as it improves their internal processes and enables the organizations to remain competitive throughout Digital Transformation.

For a sustainable adoption of the Agile PMM, it is necessary the organization's full compliance with the agile values, requiring not only the implementation of a new process, but also a brand new mindset (Tolfo, Cristiano; Wazlawick, Raul Sidney; Gomes Ferreira, Marcelo; Forcellini, 2009). Since the agile philosophy is people-centered, rather than process-centered, the greatest challenges brought by its implementation are related to the human aspects, such as leadership style, team's resistance, collaboration and ownership, which are not easily changed (Gandomani, Zulzalil, Ghani, Abu, \& Sharif, 2014; Gandomani, Zulzalil, Ghani, Sultan, et al., 2013; Javdani Gandomani \& Ziaei Nafchi, 2016; Nerur, Mahapatra, \& Mangalaraj, 2005; Taghi Javdani Gandomani et al., 2014; Tolfo, Cristiano; Wazlawick, Raul Sidney; Gomes Ferreira, Marcelo; Forcellini, 2009).

This article analyzes the publications related to the transition of traditional organizations to Agile PMM, focusing on human aspects, due to their relevance to this new process. Its main goal is to provide information about these challenges to organizations willing to experience this transition. Based on these challenges, some recommendations will be proposed with the objective of reducing the transition risks and their impact on people (Conboy, Coyle, Xiaofeng Wang, \& Pikkarainen, 2011; Gandomani, Zulzalil, Ghani, \& Sultan, 2013; Javdani Gandomani \& Ziaei Nafchi, 2016; Nerur et al., 2005). This knowledge is extremely important for organizations needing to adopt

1) Departamento de Administração, Faculdade de Economia, Administração e Contabilidade, Universidade de São Paulo, São Paulo, Brazil

*Corresponding author: mariangelap@usp.br

ISSN: 0718-2724. (http://jotmi.org)

Journal of Technology Management \& Innovation (c) Universidad Alberto Hurtado, Facultad de Economía y Negocios. 
increasingly efficient models for the development of innovative products and services in order to stand out in the current competitive scenario, without overlooking their corporate strategy.

\section{Discussion}

\section{Project Management Models}

PMMs are sequences of techniques and skills aimed to assist on projects execution according to best practices, besides monitoring milestones, costs and resources associated with projects execution. They were formalized in the 1960s, following the creation of PMI - Project Management Institute - in the United States (www.pmi.org) and were soon spread worldwide. Their main objective is to create processes to assist Project Management in different industries, such as technology, manufacture and construction. They are based on project planning and tasks which are planned and monitored sequentially. In this paper, these models are described as Traditional Project Management Models.

The sequential process of Traditional PMMs has been largely criticized in the last decades due to its difficulty in adapting to the new competitive market. The current fast paced scenario demands projects to be implemented in the shortest possible time. However, considering the present uncertain environment, it is hard to define all project requirements during the planning phase, which results in several change requests throughout its execution, when new requirements are identified. This leads to customer's dissatisfaction, since changes usually result in additional time and cost to the project. Bearing that in mind, those projects displayed high failure rates (Mahanti, 2006) and organizations started looking for more flexible processes, in conformity with the current fast-paced market and focused on the end customer.

In this context, Agile Project Management Models emerged with a goal to simplify the bureaucratic processes proposed by Traditional PMMs and focus on new values not previously looked at (Boehm, 2002). These models are better adapted to the current dynamic market, as they have a greater tolerance to change and target at delivering products that customers wish in a shorter time-to-market (Chen et al., 2016). During the last decades, Agile PMMs have gained great popularity (Nerur et al., 2005) and organizations are increasingly realizing their need for agile project execution (Cao, Xu, \& Ramesh, 2009).

\section{Traditional Project Management Models}

Traditional PMMs are based on project planning and well-defined phases, generally executed sequentially. The formal documents related to scope, cost, and schedule must be defined during the project planning phase, and only after its completion can the project be executed. All these artifacts set out in project planning should be tracked during monitoring phase, including performance indicators, in order to identify schedule and cost variations, apart from risks and issues. During monitoring phase, change requests are also managed and impacts on cost and schedule must be accepted by the customer.
Due to these features, Traditional PMMs fit better stable environments or projects that require advance planning, such as fixed-scope contracts. In addition, they can also be recommended for large and complex projects, or projects with distributed teams, so that documentation can be shared and knowledge will not be lost over time (Mahanti, 2006).

However, in uncertain environments, the initial specifications may become outdated by the time the project is completed, and frequent change requests may result in late delivery of the final product, so that the organization is at risk of investing on features that do not add any value to customers.

Hence, in the last two decades, the Traditional PMMs have been considered bureaucratic and inflexible, being marked by excessive documentation and slow response to changes, whereas the market has begun to ask for simpler and more flexible models, tailored to the frequent scope changes and market speed.

\section{Agile Project Management Models}

The agile concept was consolidated in the software development industry only in 2001, with the Agile Manifesto (Beck, 2001). However, it was adapted from the lean philosophy developed in the 1950s by the Japanese automotive industry (Poth, Sasabe, Mas, \& Mesquida, 2018). The Agile Manifesto brought lean concepts to software development, such as short development cycles, rapid response to change and waste elimination, prioritizing the development of features that deliver greater value to customer (Dingsøyr, Nerur, Balijepally, \& Moe, 2012; Poth et al., 2018).

There are several Agile PMMs, each of them comprehending different concepts and activities, but all of them are based on the four values proposed by the Agile Manifesto (Gandomani, Zulzalil, Ghani, \& Sul$\tan , 2013)$ : people over processes; working software over documentation; collaboration over contract; and rapid response over a plan (Beck, 2001).

The main benefits of agile PMMs are: lower waste, improved product quality and greater flexibility to changes (Mahanti, 2006). These benefits are based on iterative and incremental approach of the project, prioritizing features that bring greater value to the customer and delivering them in short development cycles. These deliverables can be tested by the customer in a short time, resulting in rapid problem detection and representing an efficient measure of project progress. Besides, Agile PMMs are focused on communication and cooperation, supporting the concepts of minimal documentation and selforganizing teams (Boehm \& Turner, 2003).

Over the past decade, the evolution of mobility and the need for the development of new applications have given rise to the concept of lean startup (Ries, 2011), maintaining the same agile characteristics of short development cycles, waste reduction and rapid change adaptation, but displaying a greater focus on the end customer, aiming at launching products and services that meet their needs. Based on the 
Minimum Viable Product (MVP) concept, products are released to the market as early as possible, even before their whole features are developed, and customer feedback is used as criteria for prioritizing new features to be delivered.

By comparing Traditional and Agile PMMs, we can see a great concept disruption, especially related to project planning and scope definition. While in Traditional PMMs the scope is detailed at the beginning of the project and it guides cost and schedule definition, Agile PMMs work with variable scope, based on the features that can be delivered within a time frame at the highest return. After each software release, the next features to be developed can be detailed, incrementing the delivered product. Time frame is fixed, and features that will be delivered in that period are defined according to their business priority. These frequent deliveries of product pieces allow short time-to-market and rapid customer feedback. It also reduces waste by delivering features that users will actually use and enabling early bugs detection and correction. As a result, scope changes are handled more naturally, targeting mainly customer needs.

Besides, Agile PMMs have brought new focus on people, who were not targeted on Traditional PMMs. As a result, they have profoundly transformed Project Management and aligned it to the current market characteristics (Dingsøyr et al., 2012). The application of a Change Management Process is also needed during this transition, in order to reduce impact on the human aspects of the organization and allow people from all organizational levels to adjust, as smoothly as possible, to this new process.

\section{Method}

\section{Research Method}

For this study, a Qualitative Research was conducted using Kitchenham's Systematic Literature Review (SLR) (Kitchenham, 2004), due to its adherence to Software Engineering area. The research included the following phases:

\section{Research Objectives}

The first SLR phase was the objective definition, which raised the following research question: What are the main practices that should be adopted by traditional organizations undergoing agile transition to reduce its impact on people?

Moreover, the following complementary questions were defined:

Q1: Which human-related challenges were identified by the organizations during the transition to Agile Model?

Q2: What are the proposed recommendations to overcome these challenges?

\section{Research Strategy}

The literature research was performed at Scopus database (www. scopus.com). The following keywords were chosen: Agile Adoption Challenges, Agile Transformation Process and Agile Transition Framework, and the articles from the following areas were filtered: Computer Science; Engineering and Business; Management and Accounting. The selection was made on document type "article" and source type "journals", due to the selected method usage. No date filters were applied, as the topic is relatively recent, and all publications have been written after 2001 Agile Manifesto (Beck, 2001). Only articles in English were considered.

Below, there is a search example using the keyword Agile Transformation Process. The same search was performed for all other keywords:

TITLE-ABS-KEY ( Agile AND Transformation AND Process ) AND ( LIMIT-TO ( SRCTYPE, “j”) )

AND ( LIMIT-TO ( SUBJAREA, “COMP”)

OR LIMIT-TO ( SUBJAREA, "ENGI”)

OR LIMIT-TO ( SUBJAREA, "BUSI") )

AND ( LIMIT-TO ( DOCTYPE, "ar"))

AND ( LIMIT-TO ( LANGUAGE, "English”) )

\section{Document Screening}

The search using the mentioned criteria resulted in 146 articles. Then, a document screening was performed, searching for the adherence of their Title and Abstract to the proposed research question, that is, the impact of Agile Transition on people. The screening process resulted in 18 articles, excluding duplicates.

\section{Data Extraction}

After reading each of the 18 articles, the ones that did not answer the research questions were excluded, such as: studies that did not address the agile transition; studies on agile models in industries not related to software development (e.g. manufacturing); or studies that detailed the agile process, but failed to address its impacts on people.

Some articles not previously found during research phase but cited as relevant references by any of the 18 resulting articles, were also considered and added to the bibliography. These additional articles were searched by Title and Author using Google Scholar (scholar. google.com). At the end of the data extraction process, 26 articles have been analysed for this study, as detailed in Table 1:Research Process below: 
Table 1:Research Process

\begin{tabular}{l|c|c|c}
\hline \multirow{2}{*}{ Keyword } & \multicolumn{3}{c}{ Articles } \\
\cline { 2 - 4 } & Research & \multicolumn{2}{c}{ Screening } \\
\hline Agile Adoption Challenges & 47 & 9 & 16 \\
\hline Agile Transformation Process & 78 & 4 & 3 \\
\hline Agile Transition Framework & 21 & 5 & 7 \\
\hline Total & 146 & 18 & 26 \\
\hline
\end{tabular}

\section{Classification}

After carefully reading and analyzing the 26 articles, a matrix was drawn up based on the research result, identifying Author, Title, Publication Date, Abstract and Keywords (Table 2: Research Results). The articles main concepts were tracked, and their information was summarized according to qualitative criteria. Subsequently, the articles were classified by similarity and a comparative analysis was performed.
This comparison detected three categories, which the authors classified as People, Management and Organization. Challenges and recommendations were grouped into each of these categories and studied in detail, as described in Section Results.

Table 2: Research Results

\begin{tabular}{|c|c|c|c|c|c|}
\hline \# & Author & Title & Date & Abstract & Keywords \\
\hline 1 & $\begin{array}{l}\text { Ahmed Sidky } \\
\text { James Arthur } \\
\text { Shawn Bohner }\end{array}$ & $\begin{array}{l}\text { A disciplined approach to } \\
\text { adopting agile practices: the agile } \\
\text { adoption framework }\end{array}$ & 2007 & $\begin{array}{l}\text { The authors present a framework containing five agility levels, in } \\
\text { order to identify the organizations' capabilities and to determine } \\
\text { their readiness to adopt agile practices. }\end{array}$ & Agile Transition Framework \\
\hline 2 & $\begin{array}{l}\text { Alistair Cockburn } \\
\text { Jim Highsmith }\end{array}$ & $\begin{array}{l}\text { Agile software development: the } \\
\text { people factor }\end{array}$ & 2001 & $\begin{array}{l}\text { It describes people-related challenges in agile model implementa- } \\
\text { tion, focusing on both individual and team skills. }\end{array}$ & Agile adoption challenge \\
\hline 3 & Aniket Mahanti & $\begin{array}{l}\text { Challenges in Enterprise } \\
\text { Adoption of Agile Methods - A } \\
\text { Survey }\end{array}$ & 2006 & $\begin{array}{l}\text { Agile models are not suitable for all contexts. In most organi- } \\
\text { zations, a model that combines traditional and agile practices } \\
\text { is indicated. The article demonstrates how to make a successful } \\
\text { transition to agile model. }\end{array}$ & Agile adoption challenge \\
\hline 4 & $\begin{array}{l}\text { Asif Qumer } \\
\text { Brian Henderson-Sellers }\end{array}$ & $\begin{array}{l}\text { A framework to support the } \\
\text { evaluation, adoption and } \\
\text { improvement of agile methods } \\
\text { in practice }\end{array}$ & 2008 & $\begin{array}{l}\text { The article proposes the Agile Software Solution Framework } \\
\text { (ASSF) for agile transition, using the agile toolkit for technical and } \\
\text { strategic alignment. It presents two transition case studies, using } \\
\text { the Agile Adoption Improvement Model (AAIM). }\end{array}$ & Agile Transition Framework \\
\hline 5 & Barry Boehm & $\begin{array}{l}\text { Get Ready for Agile Methods, } \\
\text { with care }\end{array}$ & 2002 & $\begin{array}{l}\text { The article summarizes both traditional and agile methodologies } \\
\text { to explain the possible tools organizations may implement. }\end{array}$ & Agile adoption challenge \\
\hline 6 & $\begin{array}{l}\text { Barry Boehm } \\
\text { Richard Turner }\end{array}$ & $\begin{array}{l}\text { Management Challenges to } \\
\text { Implementing Agile Processes } \\
\text { in Traditional Development } \\
\text { Organizations }\end{array}$ & 2005 & $\begin{array}{l}\text { The authors explore the difficulties of implementing agile models } \\
\text { in traditional organizations, focusing on three areas: processes, } \\
\text { business and people. }\end{array}$ & Agile adoption challenge \\
\hline 7 & $\begin{array}{l}\text { Barry Boehm } \\
\text { Richard Turner }\end{array}$ & $\begin{array}{l}\text { Observations on Balancing } \\
\text { Discipline and Agility }\end{array}$ & 2003 & $\begin{array}{l}\text { It compares planning-based methodologies to agile methodologies } \\
\text { and proposes a process plus an action plan to achieve a balanced } \\
\text { model, comprehending both traditional and agile characteristics. }\end{array}$ & Agile adoption challenge \\
\hline 8 & $\begin{array}{l}\text { Cristiano Tolfo } \\
\text { Raul Sidnei Wazlawick } \\
\text { Marcelo Gitirana Gomes } \\
\text { Ferreira } \\
\text { Fernando Antonio } \\
\text { Forcellini }\end{array}$ & $\begin{array}{l}\text { Agile methods and organiza- } \\
\text { tional culture: reflections about } \\
\text { cultural levels }\end{array}$ & 2009 & $\begin{array}{l}\text { This article explores the organizational culture with the object } \\
\text { of detecting problems in advance, in order to increase success } \\
\text { probability of adopting the agile model. }\end{array}$ & Agile adoption challenge \\
\hline 9 & $\begin{array}{l}\text { Frank Chan } \\
\text { James Thong }\end{array}$ & $\begin{array}{l}\text { Acceptance of agile methodo- } \\
\text { logies: A critical review and } \\
\text { conceptual framework }\end{array}$ & 2009 & $\begin{array}{l}\text { The article presents the challenges posed by the transition to agile } \\
\text { model, considering work habits and new team roles. It also su- } \\
\text { ggests some actions, from management perspective, to overcome } \\
\text { these challenges. }\end{array}$ & Agile Transition Framework \\
\hline 10 & $\begin{array}{l}\text { Hesam Chiniforooshan } \\
\text { Esfahani }\end{array}$ & $\begin{array}{l}\text { Transitioning to Agile: A } \\
\text { Framework for Pre-Adoption } \\
\text { Analysis }\end{array}$ & 2012 & $\begin{array}{l}\text { The author develops a framework to evaluate agile practices before } \\
\text { their adoption by the organization, aiming to identify which ones } \\
\text { are more suitable to the current context. }\end{array}$ & Agile Transition Framework \\
\hline 11 & $\begin{array}{l}\text { Ismael Edrein Espinosa- } \\
\text { Curiel } \\
\text { Josefina Rodríguez-Jacobo } \\
\text { Erika Vázquez-Alfaro } \\
\text { José Alberto Fernández- } \\
\text { Zepeda } \\
\text { Daniel Fajardo-Delgado }\end{array}$ & $\begin{array}{l}\text { Analysis of the changes in } \\
\text { communication and social inte- } \\
\text { ractions during the transforma- } \\
\text { tion of a traditional team into an } \\
\text { agile team }\end{array}$ & 2017 & $\begin{array}{l}\text { The agile transformation process affects formal, informal, oral and } \\
\text { written communication throghout the project. The authors of this } \\
\text { article detail five social challenges encountered in the transition } \\
\text { from traditional to agile teams. }\end{array}$ & $\begin{array}{l}\text { Agile transformation } \\
\text { process }\end{array}$ \\
\hline
\end{tabular}




\begin{tabular}{|c|c|c|c|c|c|}
\hline$\#$ & Author & Title & Date & Abstract & Keywords \\
\hline 12 & $\begin{array}{l}\text { Kieran Conboy } \\
\text { Sharon Coyle }\end{array}$ & $\begin{array}{l}\text { People over Process: Key Cha- } \\
\text { llenges in Agile Development }\end{array}$ & 2011 & $\begin{array}{l}\text { It is a case study of } 17 \text { organizations that transitioned to agile } \\
\text { model and tackled the following human challenges: recruitment, } \\
\text { training, motivation and performance evaluation. }\end{array}$ & Agile adoption challenge \\
\hline 15 & $\begin{array}{l}\text { Mike Cohn } \\
\text { Doris Ford }\end{array}$ & $\begin{array}{l}\text { Introducing an agile process to } \\
\text { an organization }\end{array}$ & 2003 & $\begin{array}{l}\text { It presents how the transition from traditional to agile methodo- } \\
\text { logies impacts not only the project team, but also other areas of } \\
\text { the company. Moreover, it describes the main challenges related to } \\
\text { this transition and provides ways to overcome them. }\end{array}$ & Agile adoption challenge \\
\hline 17 & $\begin{array}{l}\text { Minna Pikkarainen } \\
\text { Outi Salo } \\
\text { Raija Kuusela } \\
\text { Pekka Abrahamsson }\end{array}$ & $\begin{array}{l}\text { Strengths and barriers behind the } \\
\text { successful agile deployment-in- } \\
\text { sights from the three software } \\
\text { intensive companies in Finland }\end{array}$ & 2012 & $\begin{array}{l}\text { Its objective is to identify the strengths and barriers for a } \\
\text { successful agile implementation, aiming to assist companies in } \\
\text { planning the agile adoption strategy. }\end{array}$ & Agile adoption challenge \\
\hline 18 & $\begin{array}{l}\text { Peggy Gregory } \\
\text { Leonor Barroca } \\
\text { Helen Sharp } \\
\text { Advait Deshpande } \\
\text { Katie Taylor }\end{array}$ & $\begin{array}{l}\text { The challenges that challenge: } \\
\text { Engaging with agile practitio- } \\
\text { ners' concerns }\end{array}$ & 2016 & $\begin{array}{l}\text { It describes the challenges faced by agilists, which have been } \\
\text { grouped into } 7 \text { categories and } 27 \text { sub-categories. }\end{array}$ & Agile adoption challenge \\
\hline 19 & $\begin{array}{l}\text { Roger (Ronxin) Chen } \\
\text { Ramya Ravichandar } \\
\text { Don Proctor }\end{array}$ & $\begin{array}{l}\text { Managing the transition to the } \\
\text { new agile business and product } \\
\text { development model }\end{array}$ & 2016 & $\begin{array}{l}\text { The authors present the challenges and implications of the agile } \\
\text { transition by means of a case study. }\end{array}$ & Agile Transition Framework \\
\hline 22 & $\begin{array}{l}\text { Taghi Javdani Gandomani } \\
\text { Hazura Zulzalil } \\
\text { Abdul Azim Abdul Ghani } \\
\text { Abu Bakar Md. Sultan } \\
\text { Mina Ziaei Nafchi }\end{array}$ & $\begin{array}{l}\text { Obstacles in moving to agile soft- } \\
\text { ware development methods }\end{array}$ & 2013 & $\begin{array}{l}\text { This study focuses on the challenges faced by organizations } \\
\text { undergoing agile transition. These challenges are grouped into } \\
\text { four categories: organization and management; people; process; } \\
\text { and tools. }\end{array}$ & Agile adoption challenge \\
\hline 23 & $\begin{array}{l}\text { Taghi Javdani Gandomani } \\
\text { Hazura Zulzalil, } \\
\text { Abdul Azim Abdul Ghani, } \\
\text { Abu Bakar Md. Sultan } \\
\text { Khaironi Yatim Sharif }\end{array}$ & $\begin{array}{l}\text { How Human Aspects Impress } \\
\text { Agile Software Development } \\
\text { Transition and Adoption }\end{array}$ & 2014 & $\begin{array}{l}\text { This article approaches the human aspects of agile transformation } \\
\text { through a study with } 32 \text { Agile Experts using Grounded Theory. }\end{array}$ & Agile transformation process \\
\hline 24 & $\begin{array}{l}\text { Taghi Javdani Gandomani } \\
\text { Mina Ziaei Nafchi }\end{array}$ & $\begin{array}{l}\text { Agile transition and adoption } \\
\text { human-related challenges and } \\
\text { issues: A Grounded Theory } \\
\text { approach }\end{array}$ & 2016 & $\begin{array}{l}\text { It explains that the main challenges in agile transition are related } \\
\text { to organizational mindset change, as the agile model is turned to } \\
\text { people rather than to processes. }\end{array}$ & Agile adoption challenge \\
\hline 25 & $\begin{array}{l}\text { Taghi Javdani Gandomani } \\
\text { Mina Ziaei Nafchi }\end{array}$ & $\begin{array}{l}\text { An empirically-developed fra- } \\
\text { mework for Agile transition and } \\
\text { adoption: A Grounded Theory } \\
\text { approach }\end{array}$ & 2015 & $\begin{array}{l}\text { This article offers a framework for the transition to agile model by } \\
\text { using Grounded Theory. }\end{array}$ & Agile Transition Framework \\
\hline 26 & $\begin{array}{l}\text { Torgeir Dingsøyra } \\
\text { Sridhar Nerur } \\
\text { VenuGopal Balijepally } \\
\text { Nils Brede Moe }\end{array}$ & $\begin{array}{l}\text { A decade of agile methodolo- } \\
\text { gies: Towards explaining agile } \\
\text { software development }\end{array}$ & 2012 & $\begin{array}{l}\text { It presents the agile model evolution throghout the decade since } \\
\text { the Agile Manifesto and includes the authors' contribution. }\end{array}$ & Agile adoption challenge \\
\hline
\end{tabular}




\section{Results}

Agile PMMs have provided a deep transformation in project management and execution compared to previous traditional models. While Agile PMMs focus on people and their interaction, Traditional PMMs focused only on executing formal processes (Dingsøyr et al., 2012; Nerur et al., 2005) during project implementation.

In order to meet customer demands and reduce products launching time-to-market, many organizations are transforming their software development processes from traditional, planning-based and centralized control models, into agile ones, which accept changes on a more natural way and are based on decision sharing (Cockburn, Alistair; Highsmith, 2001).

Nonetheless, implementing the agile model does not guarantee the project success, and organizations still need to promote holistic adjustments to the new model, not only referring to software development processes, but also to organizational mindset (Boehm, 2002; Dikert, Paasivaara, \& Lassenius, 2016).

Due to the disruption from the previous model, the organization transition from a Traditional to an Agile PMM is not simple and it can be time-consuming. Since Agile PMMs are people-centered, rather than process-centered, the main challenges of this transition are not related to its technical aspects, but to human ones, as they require the organization adaptation to the agile values (Gandomani, Zulzalil, Ghani, \& Sultan, 2013; Javdani Gandomani \& Ziaei Nafchi, 2015, 2016).

For this reason, it is important to further analyze the impact of agile transformation on the organization's staff, including new roles and responsibilities they should perform under the agile process. The lack of knowledge about these challenges turns this transition even more difficult to be planned, executed and managed (Conboy et al., 2011; Gandomani, Zulzalil, Ghani, \& Sultan, 2013; Javdani Gandomani \& Ziaei Nafchi, 2016; Jovanović, Mas, Mesquida, \& Lalić, 2017; Nerur et al., 2005). Furthermore, the compatibility between agile philosophy and organization values must be taken into account even before the transition starts (Tolfo, Cristiano; Wazlawick, Raul Sidney; Gomes Ferreira, Marcelo; Forcellini, 2009).

Bearing that in mind, the following section will describe the main challenges impacting the human aspects of the organization, as well as the proposed recommendations.

The challenges have been grouped into People, Management and Organizatio

\section{People}

People challenges are related to changes in roles, responsibilities, skills and activities demanded by the project team. These changes are essential, as the agile adoption requires high-performance and multidisciplinary teams, which display greater autonomy and focus on collaboration and communication. A summary of people challenges is described in Table 3:People.

To ensure a smooth transition to the agile model, it is important to achieve the buy-in of the entire team taking part of the new process (Conboy et al., 2011). When the transition is made top-down, without informing the team about the features and benefits of the new model, they may be more resistant to adjusting to agile practices. On the other hand, if the agile transition is not mandatory, it may not be effective either, since the team will not be motivated to run the transformation (Chan \& Thong, 2009).

For that reason, it is crucial for the organization management to communicate the transition goals and benefits, so that the team will have clear expectations about its process and will actively participate in the transformation (Conboy et al., 2011; Javdani Gandomani \& Ziaei Nafchi, 2015, 2016; Jovanović et al., 2017; Mahanti, 2006). Whenever there is a lack of knowledge about the transition objectives, the team is more likely to offer resistance or show unrealistic expectations, leading to frustration or demotivation. 
Table 3:People

\begin{tabular}{|c|c|c|c|}
\hline Category & Challenges & Recommendations & Supporting Authors \\
\hline Resistance to change & $\begin{array}{l}\text { Since most agile changes are related to } \\
\text { people, the team may resist and face difficul- } \\
\text { ties adapting to agile practices. }\end{array}$ & $\begin{array}{l}\text { The management should communicate the } \\
\text { transition goals to the team, so that they will } \\
\text { have clear expectations about the agile process } \\
\text { and practices. In addition, the agile adoption } \\
\text { should be mandatory for the whole organiza- } \\
\text { tion, otherwise the staff will not be motivated } \\
\text { to change. }\end{array}$ & $\begin{array}{l}\text { Conboy et al. (2011) } \\
\text { Dikert et al. (2016) } \\
\text { Gandomani et al. (2014) } \\
\text { Javdani Gandomani \& } \\
\text { Ziaei Nafchi }(2015,2016) \\
\text { Jovanović et al. (2017) } \\
\text { Mahanti (2006) }\end{array}$ \\
\hline Decision Making & $\begin{array}{l}\text { Project managers are resistant to giving up } \\
\text { their authority, so the project team maintains } \\
\text { a passive attitude rather than taking responsi- } \\
\text { bility for themselves. }\end{array}$ & $\begin{array}{l}\text { The Project Manager should act as a facilita- } \\
\text { tor, by encouraging all the team members to } \\
\text { contribute to project decision-making. The } \\
\text { project team must take on a leading role and be } \\
\text { self-organized. }\end{array}$ & $\begin{array}{l}\text { Boehm \& Turner (2005) } \\
\text { Chen et al. (2016) } \\
\text { Conboy et al. (2011) } \\
\text { Espinosa-Curiel et al. } \\
\text { (2018) } \\
\text { Gandomani et al. (2013, } \\
\text { 2014) } \\
\text { Javdani Gandomani et al. } \\
\text { (2016) } \\
\text { Nerur et al. (2005) }\end{array}$ \\
\hline Collaboration & $\begin{array}{l}\text { When project teams cannot achieve a co- } \\
\text { llaborative mindset, the transition becomes } \\
\text { much more difficult. }\end{array}$ & $\begin{array}{l}\text { All team members must act collaboratively and } \\
\text { share project ownership. }\end{array}$ & $\begin{array}{l}\text { Chan \& Thong (2009) } \\
\text { Chen et al. (2016) } \\
\text { Dikert et al. (2016) } \\
\text { Espinosa-Curiel et al. } \\
\text { (2018) } \\
\text { Gandomani et al. (2013) } \\
\text { Gregory et al. (2016) } \\
\text { Javdani Gandomani \& } \\
\text { Ziaei Nafchi (2016) } \\
\text { Jovanović et al. (2017) } \\
\text { Nerur et al. (2005) }\end{array}$ \\
\hline
\end{tabular}

Additionally, the agile model requires smaller and geographically close teams. Large projects should be split into multiple streams to ensure self-organized teams and stimulate creativity among their members (Gandomani, Zulzalil, Ghani, \& Sultan, 2013). If possible, distributed teams should be allocated in the same room, at least in the first weeks of the project, to improve interaction among team members and increase project success (Cohn \& Ford, 2003).

Agile processes also have a major impact on the team's roles and responsibilities, and all members should play a leading role in the project, rather than only the project manager (Chen et al., 2016; Javdani Gandomani \& Ziaei Nafchi, 2016). In that manner, it represents a great transformation in project decision-making process. The project manager should act only as a facilitator and be part of the final decision along with the team (Conboy et al., 2011; Nerur et al., 2005), no longer maintaining the planning and controlling roles of the traditional model (Gandomani, Zulzalil, Ghani, \& Sultan, 2013).
Therefore, it is necessary to adjust the influence power of all team members in favor of a shared leadership (Espinosa-Curiel et al., 2018). Teamwork is the key, so collaboration is of paramount relevance (Chan \& Thong, 2009; Chen et al., 2016). The entire team is responsible for work completion, so both project ownership and benefits are shared among all members. When the team fails to embrace this mindset, the transition becomes much more arduous (Javdani Gandomani \& Ziaei Nafchi, 2016).

Another important challenge refers to the project customers or users, who are a critical success factor in the implementation of agile projects (Chan \& Thong, 2009). While in traditional models, customers are nothing but stakeholders, in agile models they are considered as team members and are responsible for scope decisions and requirements prioritization.

Thus, customers should be dedicated to the project and have the same collaborative and communicative roles as any other team members 
(Conboy et al., 2011). The lack of customers' proximity and engagement can negatively impact the project, resulting in late decision-making, definition and validation of product features or backlog prioritization (Jovanović et al., 2017). It is also worth mentioning that the development team requests customers' feedback collaboratively as a way to continually adjust the process (Chen et al., 2016) towards its optimization.

\section{Management}

Management challenges refer to the transformations needed to enable agile adoption, particularly concerning leadership styles. They are summarized in Table 4:Management below.
In addition, the agile model requires a decentralized management, based on team collaboration, which is completely different from the traditional centralized model (Chen et al., 2016; Nerur et al., 2005). This feature means a drastic change in the organization's management style, often causing discomfort at the highest hierarchical levels, whose members are unwilling to give up their power in favor of the cooperation setting designed by the agile model (Gandomani, Zulzalil, Ghani, \& Sultan, 2013; Javdani Gandomani \& Ziaei Nafchi, 2016).

Table 4: Management

\begin{tabular}{|c|c|c|c|}
\hline Category & Challenges & Recommendations & Supporting Authors \\
\hline $\begin{array}{l}\text { Management } \\
\text { Support }\end{array}$ & $\begin{array}{l}\text { The organizational management may } \\
\text { act as a barrier to implementing agile } \\
\text { values. }\end{array}$ & $\begin{array}{l}\text { To apply the agile values of collaboration, } \\
\text { communication and decentralized mana- } \\
\text { gement. To embrace mindset change from } \\
\text { traditional to agile model. }\end{array}$ & $\begin{array}{l}\text { Cao et al. (2009) } \\
\text { Chan \& Thong (2009) } \\
\text { Chen et al. (2016) } \\
\text { Conboy et al. (2011) } \\
\text { Dikert et al. (2016) } \\
\text { Javdani Gandomani \& Ziaei Nafchi }(2015,2016) \\
\text { Jovanović et al. (2017) } \\
\text { Mahanti (2006) } \\
\text { MilošJovanovic (2017) } \\
\text { Taghi Javdani Gandomani et al. (2014) }\end{array}$ \\
\hline $\begin{array}{l}\text { Descentralized } \\
\text { Management }\end{array}$ & $\begin{array}{l}\text { Traditional models preach command } \\
\text { and control management, while agile } \\
\text { models are based on collaboration. } \\
\text { The management's difficulty in accep- } \\
\text { ting the decentralized model reduce } \\
\text { their power. }\end{array}$ & $\begin{array}{l}\text { To reduce micromanagement at managerial } \\
\text { levels and delegate decision making. To } \\
\text { redefine project controlling expectations and } \\
\text { management reports. }\end{array}$ & $\begin{array}{l}\text { Chen et al. (2016) } \\
\text { Cockburn, Alistair; Highsmith (2001) } \\
\text { Cohn \& Ford (2003) } \\
\text { Espinosa-Curiel et al. (2018) } \\
\text { Gandomani et al. (2013) } \\
\text { Gregory et al. (2016) } \\
\text { Javdani Gandomani \& Ziaei Nafchi (2016) } \\
\text { Nerur et al. (2005) }\end{array}$ \\
\hline
\end{tabular}

Therefore, there is a great transformation in leadership roles after the implementation of agile processes, as leaders will have to give up micromanagement, giving support for the removal of project barriers, while teams will be empowered and encouraged to take decisions (Chen et al., 2016).

Project planning and monitoring can be great examples of mindset shift, as the agile model does not convey, at first, a clear vision of project schedule and total investment needed. The management team will not have access to precise time and costs estimates, nor will they be able to monitor the project progress through reports, as they were used to (Cohn \& Ford, 2003).

As a result, it is important that the organization's management replace their controlling expectations - which were previously based on scope, cost and time - by a new controlling system based on quality and business value (Gregory, Barroca, Sharp, Deshpande, \& Taylor, 2016). This change should not be perceived as lack of control, but as an adherence to the new model values.

As for project reporting, considering the agile model is not focused on formal documentation, the ideal solution would be the creation of a status report template that includes general project information and some basic progress indicators to be distributed among project managers (Cohn \& Ford, 2003). However, when checking project status, the board should direct their attention to reviewing partial deliverables of the running software, rather than just reviewing reports.

Old management expectations towards traditional project planning and monitoring are no longer functional after agile transition, and they may offer a hindrance to the new process adoption (Cockburn, Alistair; Highsmith, 2001). Therefore, the adjustment to the new values of shared leadership and decentralized power are compulsory for a successful transition. Organization

\section{Organization}

The organization challenges are related to the essential changes in staff's recruiting, training and performance evaluation, as well as in the hierarchical structure following agile transition. These changes must be held by the whole organization, including Human Resources, so that the new practices can be successfully internalized. A summary of organizational challenges can be found in Table 5:Organization below. 
One of the most crucial actions to be taken before the transition process starts is investing in training, not only for the project members, but also for the members of all departments, including the ones of higher hierarchical levels. As agile models are quite different from traditional ones, the teams will take some time adapting to this new mindset.

Table 5: Organization

\begin{tabular}{|c|c|c|c|}
\hline Category & Challenges & Recommendations & Supporting Authors \\
\hline Training & $\begin{array}{l}\text { The organization's lack of investment in staff } \\
\text { training can pose a risk for the agile transition, } \\
\text { due to staff's insufficient knowledge of agile } \\
\text { processes and values. }\end{array}$ & $\begin{array}{l}\text { To promote training on agile pro- } \\
\text { cesses and values, as well as business } \\
\text { skills and necessary soft skills (com- } \\
\text { munication and cooperation). }\end{array}$ & $\begin{array}{l}\text { Chan \& Thong (2009) } \\
\text { Conboy et al. (2011) } \\
\text { Dikert et al. (2016) } \\
\text { Gandomani et al. (2013) } \\
\text { Gregory et al. (2016) } \\
\text { Jovanović et al. (2017) } \\
\text { Mahanti (2006) } \\
\text { Miloš Jovanovic (2017) }\end{array}$ \\
\hline $\begin{array}{l}\text { Agile Transforma- } \\
\text { tion Team }\end{array}$ & $\begin{array}{l}\text { Difficulty to implement agile principles and } \\
\text { values, such as collaboration, communication } \\
\text { and teamwork, in addition to adopt practices, } \\
\text { such as sprints and ceremonies. }\end{array}$ & $\begin{array}{l}\text { To offer agile training to the project } \\
\text { team. To hire an outsourced coach } \\
\text { to support the transition process. To } \\
\text { establish a transition team to reinforce } \\
\text { the model application. }\end{array}$ & $\begin{array}{l}\text { Conboy et al. (2011) } \\
\text { Dikert et al. (2016) } \\
\text { Espinosa-Curiel et al. (2018) } \\
\text { Gandomani et al. (2013, 2014) } \\
\text { Gregory et al. (2016) } \\
\text { Javdani Gandomani \& Ziaei Nafchi (2016) } \\
\text { MilošJovanovic (2017) } \\
\text { Nerur et al. (2005) }\end{array}$ \\
\hline $\begin{array}{l}\text { Participation of } \\
\text { other areas }\end{array}$ & $\begin{array}{l}\text { Difficulties caused by lack of engagement from } \\
\text { other areas. }\end{array}$ & $\begin{array}{l}\text { To provide staff with top down } \\
\text { explanation on the relevance of using } \\
\text { the same model in all departments, in } \\
\text { order to prevent negative impact on } \\
\text { the project execution. }\end{array}$ & $\begin{array}{l}\text { Cohn \& Ford (2003) } \\
\text { Dikert et al. (2016) }\end{array}$ \\
\hline $\begin{array}{l}\text { Hierarchical } \\
\text { Structure }\end{array}$ & $\begin{array}{l}\text { Team formation is no longer based on functio- } \\
\text { nal areas, but on multidisciplinary teams, which } \\
\text { demand a change in role structure. }\end{array}$ & $\begin{array}{l}\text { To promote changes in hierarchi- } \\
\text { cal levels in the interest of a more } \\
\text { horizontal structure throughout the } \\
\text { organization. }\end{array}$ & $\begin{array}{l}\text { Conboy et al. (2011) } \\
\text { Javdani Gandomani \& Ziaei Nafchi (2016) }\end{array}$ \\
\hline Recruitment & $\begin{array}{l}\text { As the agile model is more connected to multi- } \\
\text { disciplinary traits, certain profiles are no longer } \\
\text { valued to organizations. }\end{array}$ & $\begin{array}{l}\text { To hire qualified professionals who } \\
\text { display both technical and business } \\
\text { skills, according to agile values. }\end{array}$ & $\begin{array}{l}\text { Conboy et al. (2011) } \\
\text { Mahanti (2006) } \\
\text { Gregory et al. (2016) }\end{array}$ \\
\hline $\begin{array}{l}\text { Performance } \\
\text { Evaluation }\end{array}$ & $\begin{array}{l}\text { The performance appraisal cannot consider } \\
\text { only individual merits, as the traditional models } \\
\text { used to. }\end{array}$ & $\begin{array}{l}\text { To assess team merits and take } \\
\text { into consideration collaboration, } \\
\text { communication, and integration ca- } \\
\text { pabilities. To develop new evaluation } \\
\text { metrics, including group performance } \\
\text { indicators and reward systems. To } \\
\text { increase motivation by granting more } \\
\text { flexibility to career management and } \\
\text { developing internal opportunities. }\end{array}$ & $\begin{array}{l}\text { Chan \& Thong (2009) } \\
\text { Chen et al. (2016) } \\
\text { Conboy et al. (2011) } \\
\text { Espinosa-Curiel et al. (2018) } \\
\text { Javdani Gandomani \& Ziaei Nafchi (2016) }\end{array}$ \\
\hline
\end{tabular}

Apart from agile processes, the training should include knowledge about soft skills, such as communication, teamwork and presentation techniques, along with general business knowledge, as the significant changes in hierarchical structure will compel team members to take the lead and interact with higher hierarchical levels (Conboy et al., 2011).

Whenever possible, the organization should assign an agile transformation team to set transition goals in line with the organizational context. It is also important to hire an external coach to support this transition (Gandomani, Zulzalil, Ghani, \& Sultan, 2013) by guiding the organization through this process and providing feedback about the ongoing process (Chan \& Thong, 2009). Additionally, it is recommended to implement a pilot project, so that staff can gradually follow the new practices and later expand them to other projects, after the process is already operational.

Furthermore, it is critical that all organization departments abide by the agile process. The success chances of having different areas executing different models (e.g. business areas using a traditional model and technical areas using an agile model) are considerably low. The board should communicate to the whole organization about the importance of adopting and complying with the process established by the project team, in order to reinforce agile transformation (Cohn \& Ford, 2003).

Regarding the hierarchical structure, it should be replaced by a more horizontal structure, considering the agile model expects decisions to 
be made by all team members. The team structure should no longer be based on functional areas, but rather in multidisciplinary teams (Conboy et al., 2011; Javdani Gandomani \& Ziaei Nafchi, 2016).

One measure that can minimize the agile transition impact on people is the gradual and iterative implementation of the new model, starting by employing some practices that deliver greater business value. As the team gets adapted to these practices, new ones will be gradually included, as per the continuous improvement concept (Campanelli, Camilo, \& Parreiras, 2018; Cohn \& Ford, 2003; Gandomani, Zulzalil, Ghani, \& Sultan, 2013; Javdani Gandomani \& Ziaei Nafchi, 2016; Qumer \& Henderson-Sellers, 2008).

Human Resources should follow suit, directing efforts to hire qualified professionals with both technical and business skills (Conboy et al., 2011). The employee performance evaluation model must be altered, so that collaboration, communication and team integration make part of performance criteria. Besides, corporate assessment metrics should add group performance indicators in addition to individual ones (Chen et al., 2016; Cohn \& Ford, 2003; Javdani Gandomani \& Ziaei Nafchi, 2016). Finally, Human Resources should carry out a career plan that rewards employees based on their skills as a way to encourage them to pursue the transition (Chan \& Thong, 2009).

\section{Conclusions}

For traditional organizations to remain competitive in this new and uncertain environment, it is essential that they execute the agile transition as part of their Digital Transformation process. The benefits of the Agile PMM are higher focus on customer needs, short development cycles, faster product delivery and waste elimination. These benefits enable new agile models to better adapt to the current market, as it is much more dynamic, demanding a constant delivery of innovative products and services.

The Agile Manifesto (Beck, 2001) has triggered a profound transformation in Project Management Models, especially in the software development industry, as it urged organizations to move from a bureaucratic process-based model to a simplified and people-based one, by bringing up values of empowerment, collaboration and communication. These values involve a higher focus on human aspects and the disruption from formal and hierarchical values of traditional models.

In spite of its advantages, the transition to Agile PMMs takes time and effort on organizations' part, since it relies not only on changes referring to process, but also to the mindset of the whole organization (Gandomani, Zulzalil, Ghani, \& Sultan, 2013). Hence, these challenges may represent a limitation for agile adoption.

The duality between benefits and challenges has been the subject of several academic studies aiming to find the best way to leverage the agile transition benefits, without overlooking the organizational context.

Due to this subject complexity, organizations should carefully assess the challenges encountered by other organizations which have gone through this process before starting their own transition, so that they can implement best practices and reduce risks (Conboy et al., 2011).

Among the key recommendations identified in the SLR, we highlight the support of the organization's management and the need for a clear communication to all employees about the agile transition, emphasizing its objectives and benefits.

This communication must be done before and along the transition, updating the staff on agile adoption current status and achievements. Offering training courses on Agile PMM processes and values and creating a transformation team to coordinate the process are also success factors towards minimizing team resistance.

It should be noted that the agile model is to be applied by all organizational areas, particularly by those participating in the project, such as business and technical areas. Counting on dedicated customers is one of the most important agile practices to ensure that requirements' definition and prioritization are done in the shortest time possible.

As for the new roles and responsibilities, all team members must be empowered to assume higher autonomy on decision-making process, instead of depending only on the organization management. Ownership should be shared among the team, based on collaboration and communication values, whereas the Project Manager should act as a facilitator, removing the barriers in project execution path.

Bearing that in mind, management levels must adjust their previous command and control profile to a new collaborative and decentralized one. This is one of the most painful transitions to implement, as it represents a drastic change in leadership style by interfering in the management power level. On the other hand, it is among the most critical processes to ensure a successful transformation.

In conclusion, it is recommended that the agile model implementation takes place gradually, prioritizing practices that drive the greatest business value. Then, it should evolve little by little, in an iterative way, as the teams become accustomed to the process. A pilot project could also be employed to facilitate team's adjustment to agile processes and values.

The academic literature authors argue that there is no single transition model that can fit all organizational contexts (Javdani Gandomani \& Ziaei Nafchi, 2016). Taking that into consideration, each organization should accommodate the recommendations suggested in this article to their culture in order to minimize the agile impact on their staff. That is, the processes are important, but the essence of this new model is learning how to deal with people (Campanelli et al., 2018; Cao et al., 2009).

\section{Limitations and Future Work}

This study focused only on a Systematic Literature Review of the published literature related to human aspects of agile transition, 
including qualitative and quantitative articles, empirical case studies and other relevant SLRs. As it is based on secondary data, it may contain a partial analysis of available literature.

Future work should collect primary data related to the research question, such as a qualitative research, in order to check if the recommendations found in academic literature are being put to test by any specific market with satisfying results for organizations.

\section{References}

Beck, K. et al. (2001). Manifesto for Agile Software Development. Retrieved October 29, 2018, from http://agilemanifesto.org/

Boehm, B. (2002). Get Ready for Agle Methods, with Care. International Journal of Engineering Science \& Technology, 4(1), 23-29. Retrieved from http://sunset.usc.edu/events/2002/arr/Get Ready for Agiel Methods, with Care.pdf

Boehm, B., \& Turner, R. (2003). Observations on balancing discipline and agility. In Proceedings of the Agile Development Conference, ADC 2003 (pp. 32-39). https://doi.org/10.1109/ADC.2003.1231450

Campanelli, A. S., Camilo, R. D., \& Parreiras, F. S. (2018). The impact of tailoring criteria on agile practices adoption: A survey with novice agile practitioners in Brazil. Journal of Systems and Software, 137, 366-379. https://doi.org/10.1016/j.jss.2017.12.012

Cao, L., Xu, P., \& Ramesh, B. (2009). A framework for adapting agile development methodologies. https://doi.org/10.1057/ejis.2009.26

Chan, F. K. Y., \& Thong, J. Y. L. (2009). Acceptance of agile methodologies: A critical review and conceptual framework. Decision Support Systems, 46(4), 803-814. https://doi.org/10.1016/j. dss.2008.11.009

Chen, R. (Ronxin), Ravichandar, R., \& Proctor, D. (2016). Managing the transition to the new agile business and product development model: Lessons from Cisco Systems. Business Horizons, 59(6), 635644. https://doi.org/10.1016/j.bushor.2016.06.005

Cockburn, Alistair; Highsmith, J. (2001). Agile software development: the people factor. Software Management, 131-133. https://doi. org/doi: 10.1109/2.963450

Cohn, M., \& Ford, D. (2003). Introducing an agile process to an organization. Computer, 36(6), 74-78. https://doi.org/10.1109/ MC.2003.1204378

Conboy, K., Coyle, S., Xiaofeng Wang, L., \& Pikkarainen, M. (2011). People over Process: Key Challenges in Agile Development. Ieee Software, 48-57. https://doi.org/10.1109/MS.2010.132

Dikert, K., Paasivaara, M., \& Lassenius, C. (2016). Challenges and success factors for large-scale agile transformations: A systematic literature review. Journal of Systems and Software, 119, 87-108. https:// doi.org/10.1016/j.jss.2016.06.013
Dingsøyr, T., Nerur, S., Balijepally, V., \& Moe, N. B. (2012). A decade of agile methodologies: Towards explaining agile software development. Journal of Systems and Software, 85(6), 1213-1221. https://doi. org/10.1016/j.jss.2012.02.033

Espinosa-Curiel, I. E., Rodríguez-Jacobo, J., José, E. V., Daniel, A. F., Vázquez-Alfaro, E., Fernández-Zepeda, J. A., \& Fajardo-Delgado, D. (2018). Analysis of the changes in communication and social interactions during the transformation of a traditional team into an agile team. Journal of Software: Evolution and Process, 30(9), 1-24. https://doi.org/10.1002/smr.1946

Gandomani, T. J., Zulzalil, H., Ghani, A. A. A., Abu, A. B., \& Sharif, K. Y. (2014). An Exploratory Study on Managing Agile Transition and Adoption. In Advances in Intelligent Systems and Computing. https:// doi.org/10.1007/978-3-319-06538-0_18

Gandomani, T. J., Zulzalil, H., Ghani, A. A. A., Sultan, A. B. M., \& Nafchi, M. Z. (2013). Obstacles in moving to agile software development methods; At a Glance. Journal of Computer Science, 9(5), 620-625. https://doi.org/10.3844/jcssp.2013.620.625

Gandomani, T. J., Zulzalil, H., Ghani, A. A. A., \& Sultan, M. A. B. (2013). Towards comprehensive and disciplined change management strategy in agile transformation process. Research Journal of Applied Sciences, Engineering and Technology, 6(13), 2345-2351. https://doi. org/10.19026/rjaset.6.3706

Gregory, P., Barroca, L., Sharp, H., Deshpande, A., \& Taylor, K. (2016). The challenges that challenge: Engaging with agile practitioners' concerns. Information and Software Technology, 77, 92-104. https://doi. org/10.1016/j.infsof.2016.03.003

Javdani Gandomani, T., \& Ziaei Nafchi, M. (2015). An empiricallydeveloped framework for Agile transition and adoption: A Grounded Theory approach. Journal of Systems and Software, 107, 204-219. https://doi.org/10.1016/j.jss.2015.06.006

Javdani Gandomani, T., \& Ziaei Nafchi, M. (2016). Agile transition and adoption human-related challenges and issues: A Grounded Theory approach. Computers in Human Behavior. https://doi. org/10.1016/j.chb.2016.04.009

Jovanović, M., Mas, A., Mesquida, A. L., \& Lalić, B. (2017). Transition of organizational roles in Agile transformation process: A grounded theory approach. Journal of Systems and Software, 133, 174-194. https://doi.org/10.1016/j.jss.2017.07.008

Kitchenham, B. (2004). Kitchenham_Procedures for Performing Systematic Reviews_2004.pdf. Keele University Technical Report TR/SE0401. https://doi.org/10.1.1.122.3308

Lee, M., Yun, J. J., Pyka, A., Won, D., Kodama, F., Schiuma, G., ... Jung, K. (2018). How to Respond to the Fourth Industrial Revolution, or the Second Information Technology Revolution? Dynamic New Combinations between Technology, Market, and Society through Open Innovation. https://doi.org/10.3390/joitmc4030021 
Mahanti, A. (2006). Challenges in Enterprise Adoption of Agile Methods -- A Survey. Journal of Computing \& Information Technology, 14(3), 197-206. https://doi.org/10.2498

Means, W. I., \& Schwab, B. K. (2015). The Fourth Industrial Revolution.

Nerur, S., Mahapatra, R., \& Mangalaraj, G. (2005). Challenges of migrating to agile methodologies. Communications of the ACM, 48(5), 72-78. https://doi.org/10.1145/1060710.1060712

Poth, A., Sasabe, S., Mas, A., \& Mesquida, A.-L. (2018). Lean and agile software process improvement in traditional and agile environments. Journal of Software: Evolution and Process, (July), e1986. https://doi. org/10.1002/smr.1986

Qumer, A., \& Henderson-Sellers, B. (2008). A framework to support the evaluation, adoption and improvement of agile methods in practice. Journal of Systems and Software, 81(11), 1899-1919. https://doi. org/10.1016/J.JSS.2007.12.806
Ries, E. (2011). The Lean Startup. Editora Casa da Palavra / LeYa.

Schwaber, K., \& Sutherland, J. (2017). 2017 Scrum Guide, 19(6), 504. https://doi.org/10.1053/j.jrn.2009.08.012

Taghi Javdani Gandomani, Hazura Zulzalil, Abdul Azim Abdul Ghani, Abu Bakar Md. Sultan, \& Khaironi Yatim Sharif. (2014). How Human Aspects Impress Agile Software Development Transition and Adoption. International Journal of Software Engineering and Its Applications, 8(1), 129-148. https://doi.org/10.14257/ijseia.2014.8.1.12

Tolfo, Cristiano; Wazlawick, Raul Sidney; Gomes Ferreira, Marcelo; Forcellini, F. (2009). Agile methods and organizational culture: reflections about cultural levels. JOURNAL OF SOFTWARE MAINTENANCE AND EVOLUTION: RESEARCH AND PRACTICE, (23), 423-441. https://doi.org/0.1002/smr.483 